\title{
DE
} DE GRUYTER OPEN

Arch. Min. Sci. 62 (2017), 4, 807-824

Electronic version (in color) of this paper is available: http://mining.archives.pl

DOI 10.1515/amsc-2017-0056

DANIEL KRŽANOVIĆ*\#, VESNA CONIĆ*, DEJAN STEVANOVIĆ**, BOŽO KOLONJA**, JOVAN VADUVESKOVIĆ*

\section{LONG-TERM PLANNING FOR OPEN PITS FOR MINING SULPHIDE-OXIDE ORES IN ORDER TO ACHIEVE MAXIMUM PROFIT}

\author{
PLANOWANIE DLUGOTERMINOWE WYDOBYCIA RUDY SIARCZKOWEJ \\ W KOPALNIACH ODKRYWKOWYCH W CELU UZYSKANIA MAKSYMALNEGO \\ POZIOMU ZYSKÓW
}

Profitable exploitation of mineralised material from the earth's crust is a complex and difficult task that depends on a comprehensive planning process. Answering the question of how to plan production depends on the geometry of the deposit, as well as the concentration, distribution, and type of minerals in it. The complex nature of mineral deposits largely determines the method of exploitation and profitability of mining operations.

In addition to unit operating costs and metal prices, the optimal recovery of and achievement of maximum profit from deposits of sulphide-oxide ores also depend, to a significant extent, on the level of technological recovery achieved in the ore processing procedure.

Therefore, in defining a long-term development strategy for open pits, special attention must be paid to the selection of an optimal procedure for ore processing in order to achieve the main objective: maximising the Net Present Value (NPV).

The effect of using two different processes, flotation processing and hydrometallurgical methods (bioleaching acid leaching), on determining the ultimate pit is shown in the case of the Kraku Bugaresku-Cementacija sulphide-oxide ore deposit in eastern Serbia. Analysis shows that the application of hydrometallurgical methods of processing sulphide-oxide ore achieved an increase in NPV of $20.42 \%$.

Keywords: long-term planning, optimisation, bioleaching, acid leaching, Net Present Value

Przynosząca zyski eksploatacja kopalin wydobywanych ze skorupy ziemskiej jest zadaniem złożonym i trudnym, wymagającym całościowego planowania. Aby określić w jaki sposób zaplanować prace wydobywcze, należy uwzględnić geometrię złoża, a także rozkład, koncentrację i rodzaj zawartych w złożu minerałów. Złożony charakter złóż minerałów w dużej mierze determinuje wybór metod wydobycia oraz

* $\quad$ MINING AND METALLURGY INSTITUTE BOR, ZELENI BULEVAR 35, 19210 BOR, SERBIA

** UNIVERSITY OF BELGRADE, FACULTY OF MINING AND GEOLOGY, DJUSINA 7, 11000 BELGRADE, SERBIA

\# Corresponding author: dkrzanovic@gmail.com 


\begin{abstract}
poziom zysków. Obok jednostkowych kosztów produkcji oraz cen metali, optymalna eksploatacja złóż rud siarczkowych i osiągniecie maksymalnych zysków w dużej mierze zależą także od zastosowanych technologii uzyskiwania metalu z rud. Przy definiowaniu długoterminowej strategii wydobycia rud w kopalni odkrywkowej uwzględnić także należy wybór optymalnej metody obróbki rud w celu uzyskania założonego celu: maksymalizacji wartości bieżącej netto (NPV - Net Present Value). Wykorzystanie dwóch procesów: flotacji oraz metod hydro-metalurgicznych (bio-wypłukiwanie, ługowanie) przedstawiono dla rozważanego przypadku kopalni odkrywkowej rudy siarczkowej eksploatującej złoże w regionie Kraku-Bugaresku-Cementacija we wschodniej Serbii. Analizy wskazały, że zastosowanie metod hydro-metalurgicznych zapewnia wzrost wartości bieżącej netto o $20.42 \%$.
\end{abstract}

Slowa kluczowe: planowanie długoterminowe, optymalizacja, bio-wypłukiwanie, ługowanie kwasowe, wartość bieżąca netto (NPV)

\title{
1. Introduction
}

Mining is a complex, expensive, but potentially lucrative business. Today's open pit mines are huge projects that make extensive use of automated equipment and employ the latest technology to ensure a profitable enterprise. The tight profit margins under which these mines often operate and the finicky nature of mineral markets require efficient ore removal schemes to ensure that the mine makes money.

Strategic mine planning is aimed at one goal: maximising the value to be realised from extraction of a mineral resource. This attempt at value maximisation is put into operation according to the mine planners' suggestions, or 'decisions', regarding a number of investment and scheduling alternatives, such as equipment size and placement, ore definition (determination of cut-off grade), ore access mechanics (shaft location, pit size), and ore and waste removal sequences (Davis \& Newman, 2008).

The profitable exploitation of a mineral deposit requires considerable evaluation and planning. First it must be determined what portion of the deposit can be mined economically (the mineable reserve) and what mining method should be used. Then considerable effort must be made to plan and schedule the extraction of the mineable reserve in terms of mining sequence, mining rate, mine design, equipment requirements, etc. The objective of this effort is to determine the most profitable extraction plan and the highest rate of return on investment.

The key parameters affecting open pit design are: geology, grade, localisation of mineralisation, extent of the deposit, topography, property boundaries, production rates, bench height, pit slopes, road grades, mining costs, processing costs, metal recovery, marketing considerations, strip ratios, and cut-off grades (Armstrong, 1999).

Since 1980, various methods have been used to optimise these groups of mining problems (Caccetta, 2007). For example, Linear Programming is used as the mathematical basis for solving problems related to planning work in mines (Johnson, 1969). Mixed Integer Programming is also an optimisation method used frequently to solve problems related to development work in surface mines (Caccetta \& Hill, 2003; Ramazan \& Dimitrakopoulos, 2004a, 2004b). Other methods include dynamic programming (Lerchs-Grossmann 2D algorithm, 1965; Tolwinsky \& Underwood, 1996), graph and network theory (Fan et al., 2003), and simulation (Dimitrakopoulos, 2006; Sturgul \& Li, 1997).

The Lerchs-Grossmann 3D algorithm is certainly the most important deterministic method for optimisation of surface mines. This method is widely employed in contemporary commercial applications, and in this sense constitutes the industry standard. 
GEOVIA Whittle (Dassault Systèmes Group) and NPV Scheduler (Datamine Corporate Ltd) are popular software packages based on heuristic algorithms. They apply the parametric analysis method introduced by Lerchs and Grossmann to generate a series of nested pits using different revenue factors.

When planning the mining of copper ore, the final result depends on perceiving the whole technological process of obtaining copper as a final product, carried out by means of three main processes: ore mining, ore concentration, and metallurgical treatment (roasting of ore and reduction of the obtained metal oxide are used for pyrometallurgical processes). The technological process of metallurgical treatment also includes the refinement of copper.

The aim of the paper is to conduct a comparative analysis of the achieved NPV for various technologies used in processing the sulphide-oxide copper ore being mined at the open pits operated by the company Mining and Smelting Combine Bor (RTB Bor Group). The following article examines the value of NPV for the flotation processing of ore currently being applied, as well as the value that would be achieved by means of the introduction of new processing technologies, i.e. acid leaching and bioleaching, which are being applied successfully in many mining companies worldwide and have been described in numerous scientific papers (Angelov, 2015; Nelson, 2008; Swart, 2007; Tinkler, 2009).

In low-grade deposits, including the deposits of RTB Bor Group, mining economics are very sensitive to certain parameters, such as metal recovery in the process of enrichment, production process costs along a technological sequence from excavation to metallurgical processing, and even the sequence of excavating ore bodies in large-scale deposits. Flotation recovery, which is very often different in practice from the recovery established in the mining plan, varies due to several factors; moreover, in the processing of ore containing both sulphide and oxide minerals, it also varies depending on the content of the oxide minerals.

In the technological process of obtaining the final product within the integral systems of mining and metallurgy, the presence of oxide minerals in the deposit can often lead to negative economic effects. Namely, the presence of oxides in the ore directly affects recovery in the flotation processing procedure, as the metal content in the concentrate, i.e. concentrate quality, is reduced, while flotation processing costs increase. Thus cash flows at the annual level are reduced, which also causes a reduction in the total NPV of the project.

Particular attention is devoted to consideration of the input data for implementing the technoeconomic analysis as follows:

i. Recovery in the processing procedure,

ii. Unit operating costs,

iii. Capital costs.

The values derived from these data were obtained on the basis of the historical records of the flotation processing procedure and technological tests of the RTB Bor Group (source: RTB Bor Group, 2015, Kržanović et al., 2015), i.e. based on the results of research on the potential for implementation of the acid leaching and bioleaching processes aimed at the improvement of metal recovery from copper ore mined by the RTB Bor Group (Fouillac, 2006).

The significance of this research lies primarily in the fact that the advantages of implementing acid leaching and bioleaching have been proven, in scientific terms, for an actual deposit of sulphide-oxide copper ore. The advantages refer mainly to achieving maximisation of NPV as the general aim of mining companies, i.e. to improving the economic results of manage- 
ment as a condition for the company's survival in the market, particularly in the recovery of low-grade deposits.

\section{Methodology}

The basic goal of a mining company is to reduce unit operating costs and increase the technological efficiency of ore mining and processing. This leads to increased net cash flow and profitability and helps ensure the sustainability of operations even during periods of low metal prices.

The main task of a mining company is to consider development of a number of strategies, including the use of new technologies in the entire chain of mining/metallurgy, and to choose one that will maximise NPV.

Profitable exploitation of mineral deposits requires specific kinds of assessment and planning. The procedure applied in this case study consisted of the following steps:

1) First, it was determined which part of the deposit was economical for the mine (the mineable reserve). For this purpose, a block model of the deposit was created.

2) In the second step it was determined which mining method and procedure for processing (concentration and metallurgical treatment) could be applied in the given circumstances.

3) The third step consisted of open-pit optimisation and selection of pushbacks, carried out on the basis of the unit operating costs of mining and processing, metal prices, capital costs, and recovery technologies in the processing processes.

4) The fourth step was schedule optimisation.

5) Finally, in the fifth step, annual discounted cash flows, i.e. total NPV, were calculated.

The aim of these efforts was to determine the most profitable mining plan and the highest rate of return. These tasks are performed as part of long-term planning (LTP).

Before initiating detailed planning of the mine, it is necessary to estimate the mineral resources. While geostatistical techniques are of great assistance in ore-body modelling, misclassifications still occur in evaluations of mine projects which use an estimated ore-body model.

To minimise the possibility of misclassification of resources/reserves, the geologist normally resorts to techniques based on spatial stochastic models (geostatistics) and computational methods, which model the spatial uncertainty of the ore body at non-sampled locations. This is done by interpolating data from several exploration samples. These techniques can be classified into two groups. The first corresponds to an estimation method based on deterministic linear techniques, such as ordinary kriging (David, 1973; David et al., 1974), a conditional expectation accounting for local variability. The second group corresponds to an estimation method based on conditional simulation techniques, such as sequential Gaussian simulation (SGS) (Journel \& Kyriakidis, 2004) based on the Monte Carlo method, which accounts for global variability.

There are a number of ways to write an expression for block value. The one used in this paper is as follows (Whittle User's Guide, 2014):

VALUE $=($ METAL $\times$ RECOVERY $\times$ PRICE - ORE $\times$ COSTP $)-$ ROCK $\times$ COSTM 
where the part in parentheses is repeated for each separately mineable ore parcel in the block, and where:

- METAL $=$ the number of units of product in the ore parcel, i.e. tons of ore multiplied by grade;

- RECOVERY = the proportion of product recovered by processing the ore;

- PRICE $=$ the price that can be obtained per unit of product sold;

- ORE $=$ the number of tons of ore in the ore parcel;

- COSTP = the extra cost per ton of mining the material as ore and processing it, rather than treating it as waste;

- ROCK $=$ the total amount of rock (ore and waste) in the block;

- $\operatorname{COSTM}=$ the cost of mining a ton of waste.

Based on the size of a deposit, its grade distribution, and other physical characteristics, mining engineers can estimate the scale of a feasible mining operation and thus determine the size and extent of mining equipment and overall excavating capacities.

In the exploitation of sulphide-oxide ore, one of the conditions for achieving maximum overall NPV is the realisation, in the process of concentration and metallurgical processing, of:

- optimal recovery;

- minimisation of unit operating costs.

Based on this, in this case study, the NPV was analysed for two types of processing, as follows:

1) the existing flotation method;

2) the hydrometallurgical process (bioleaching and acid leaching).

In the first case, the concentrate is sent to the smelter, where the ore is roasted, resulting in reduction of the metal oxide, and subsequently refined.

In the second case, the hydrometallurgical process of copper extraction means both bacterial leaching of copper sulphide ore and acid leaching of copper oxide ore. Through bioleaching (microorganisms) and acid leaching, copper is dissolved from the ore using weak sulphuric acid (Conić, 2015). Then copper passes from the chemical into the ion form to yield easily soluble sulphates. In practice, in order to carry out leaching on formed heaps, the ore is usually placed on pads to collect solutions, which are further treated by the method of solvent extraction (SX) and electrolytic extraction (EW).

With basic knowledge of mining equipment, a mining engineer can then determine the rough operating costs per ton of excavated material. Similarly, the rough processing costs per ton of ore can be determined. Once operating costs have been determined and geotechnical characteristics investigated, the engineering team can design the ultimate pit.

The optimal outline is defined using Whittle software. According to the methodology, determination of the Whittle optimisation algorithm can be roughly divided into three steps:

- generating the shells of open pits;

- determining the best and the worst mining scenarios;

- selecting the ultimate pit using graphics of change and defining the optimum contour depending on revenue factor.

The Whittle method starts by performing 50 to 100 optimisations using the Lerchs-Grossmann algorithm iteratively for several prices of useful mineral resources. In this approach, a series of 
open pits of different sizes is obtained, whereby each open pit is assigned a maximum undiscounted cash value in relation to the relevant price of useful mineral raw resources (Whittle, 1999).

In order to avoid the circular problem arising from an inability to optimise the limits of the open pit without knowledge of the discounted economic value of the blocks, which is impossible to determine without knowing the sequence of excavation, as well as the problem of determining the sequence of excavation without an optimal contour, a procedure for determining the best and the worst mining scenario was introduced in the Whittle algorithm. Using this approach, the circular problem is partly avoided, and with a rough definition of excavation sequence (the best and worst mining scenarios) it is possible to determine a preliminary sequence of excavation or the discounted value of formed optimum contours.

Software for generating the nested open pits and defining the pushbacks uses a technique of parameterisation (revenue factors); the calculation is based on undiscounted cash values. The choice of a shell as the ultimate open pit border is made by the engineers who deal with planning and management, and a selection is made in accordance with the company's objectives.

The main reason for planning the pushbacks is economic, i.e. to maximise net present value.

In defining the pushbacks, the following requirements must be met (Kržanović et al., 2014):

- a minimum allowable distance between pushback boundaries;

- a minimum working width for each pushback bottom;

- a positive NPV for each pushback;

- the maximum NPV for a defined pushback.

Schedule optimisation is carried out in the next step. The analysis is based on the Milawa algorithm supported by Whittle software, and is designed specifically for defining mining dynamics within a long-term exploitation planning strategy. The Milawa algorithm can run either in NPV mode, whereby it will seek to maximise NPV, or balancing mode, whereby it will seek to maximise the use of the production capacity of the plant in the early years of the mine's life.

The final step presents the use of the method of discounted cash flow (DCF) in order to obtain the highest net present value (NPV).

The net present value of a business with a finite life can be calculated by discounting a series of cash flows. In order to calculate the net present value, the cash flows must include all costs and revenues of the project. The net present value is often used as the criterion for increasing the long-term shareholder.

The following formula shows how NPV is calculated from a series of cash flows using a constant discount rate $\delta$ over the operation's life:

$$
\mathrm{NPV}=\sum_{\text {year }=1}^{\text {life }} \frac{\text { Cashflow }_{\text {year }}}{(1+\delta)^{\text {year }}}
$$

This formula discounts cash flow to its value at the beginning of the first year and assumes that cash flow occurs at the end of each year.

As can be seen from equation (2), there are only two parameters that can impact the net present value of the deposit: the discount rate and annual cash flow. 


\section{Case study}

The Kraku Bugaresku Cementacija ore field is part of the complex of ore deposits at the Cerovo Mali Krivelj site (a porphyry deposit in the Carpathian Balkan metallogenic belt, in the Bor metallogenic area, Eastern Serbia), differing from the rest of the deposits in its manner of occurrence and type of mineralisation. It falls within the cementation zone of secondary enrichment, in which oxide mineralisation forms part of overall mineralisation. The ore field consists of the Kraku Bugaresku Cementacija ore bodies 1, 2, 3, and 4, of which ore bodies 3 and 4, according to content of oxide ore in relation to total reserves, are separate. This deposit is mined by the Mining and Smelting Complex Bor Group (RTB Bor Group). As indicated by the copper content, it is classified among low-grade deposits for which the economics of exploitation is very sensitive to certain parameters, such as metal recovery in the enrichment process, operating costs in the technological chain from mining to metallurgical treatment, and even the sequence of mining the ore bodies of the cementation zone.

Copper sulphides in the deposit are present in the form of the minerals covellite, chalcocite, chalcopyrite, and pyrite, while copper oxide is present in the form of the minerals cuprite, malachite, chrysocolla, and azurite.

Interpretation of the deposit and the surrounding area in the form of a block model was carried out through the division of the space which covers the deposit into blocks of regular dimensions. Each block contains unique information in terms of the volume it contains within a three-dimensional (3D) space. This means that each block has its own location, size, and quality characteristics in 3D space (type of rock, density, grade of the basic useful component $\mathrm{Cu}(\%)$ and accompanying components $\mathrm{S}(\%), \mathrm{Au}(\mathrm{g} / \mathrm{t})$, and $\mathrm{Ag}(\mathrm{g} / \mathrm{t})$, economic value of the block, and profit to be realised by excavation of that block). Blocks within the model are characterised by a basic size of $15 \times 15 \times 15 \mathrm{~m}$.

To determine the maximum allowed percentage of copper oxide in total copper oxide, as a result of which the flotation process takes place without negative consequences, technological tests were carried out. The results showed that the flotation recovery of ore with a copper oxide grade $\leq 10 \%$ is at the level of $80 \%$, which is considered optimal recovery (Mining and Smelting Complex Bor Group, 2015). For further analysis, two types of ore are separated in the block model of the deposit: Ore 1 with a copper oxide grade $\leq 10 \%$ and Ore 2 with a copper oxide grade $>10 \%$, Fig. 1 (Kržanović at al., 2015).

High-capacity mining equipment is applied to ore and waste mining in the operations of drilling, blasting, loading, and transport. In order to achieve the optimum parameters, the processes of mining Ore 1 and Ore 2 are carried out selectively.

The existing technology for ore processing at the Cerovo site includes the following operations:

- primary crushing;

- secondary and tertiary crushing;

- two-stage grinding with rods and balls;

- thickening of the grinding products and obtaining pulp of $38 \%$ of solid stage.

The pulp is hydraulically transported to the Veliki Krivelj flotation plant, where the flotation concentration of copper minerals, consisting of the following processes, is carried out:

- conditioning (pulp is diluted to $25 \%$ of solid stage; lime milk is added along with the required quantity of reagents); 


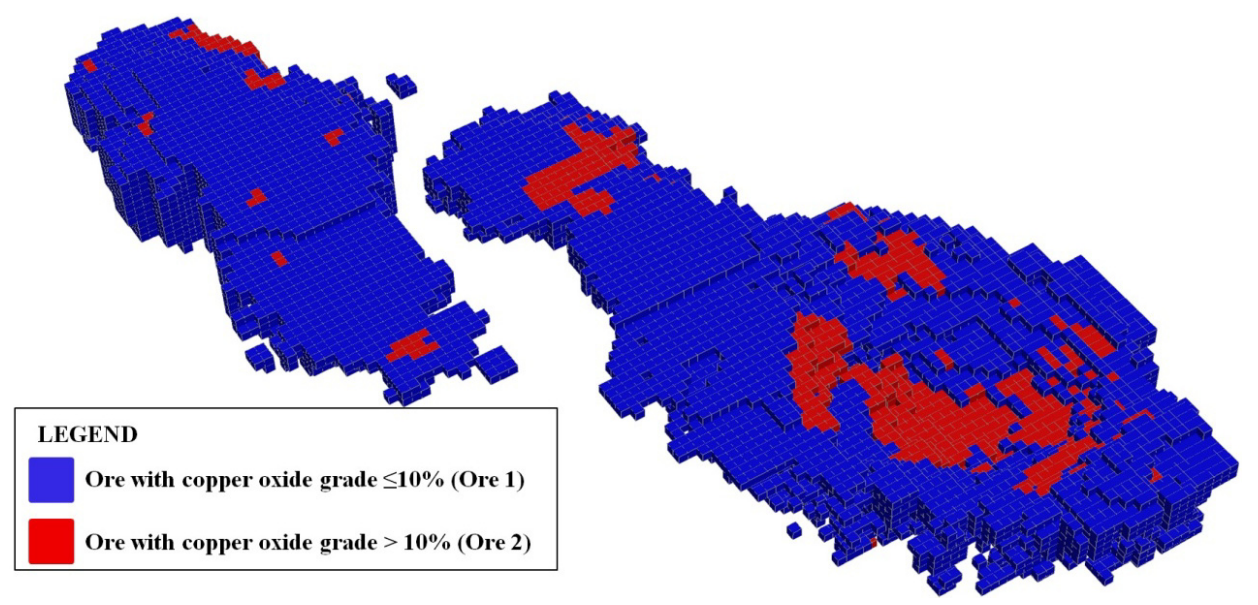

Fig. 1. Two types of ore in the block model of the Kraku Bugaresku Cementacija copper deposit

- basic flotation;

- regrinding of the basic concentrate;

- refining of the copper concentrate in three stages (levels I, II, and III).

The product of stage III of refining represents a definitive copper concentrate which is transported by pumps to be drained. Following the flotation process, copper concentrate is sent to the smelter and to refining, where the final product, copper cathode, is obtained.

A technological schema of the existing mining technology and processing of copper minerals from the ore of the Kraku Bugaresku Cementacija deposit is shown in Fig. 2.

The application of the new technology for the processing of ore from the Kraku Bugaresku Cementacija deposit, i.e. the hydrometallurgical method of copper extracting (bioleaching acid leaching), results in:

- increased ore efficiency from deposits;

- increased processing efficiency;

- reduced unit operation costs.

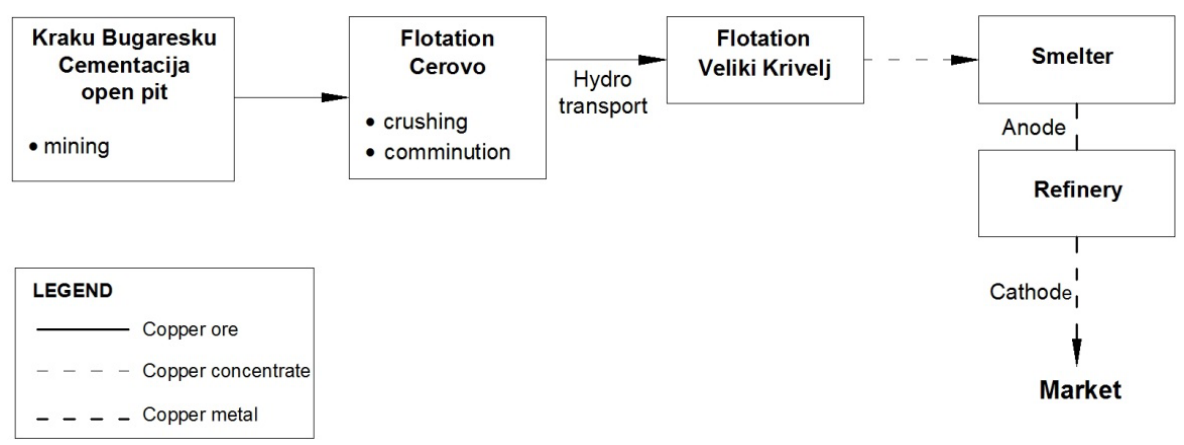

Fig. 2. Technological schema of the existing mining and ore processing technology in the Kraku Bugaresku Cementacija deposit 
One unfavourable circumstance is the significant existing investment in industrial plants; as a result, it is only after economic analysis that a determination can be made as to which strategy is more favourable, i.e. which yields a higher profit.

Leaching technology used on a formed heap means that the blasted ore is comminuted and then layered in sets 3 to $9 \mathrm{~m}$ in height. The first layer is placed on an impermeable membrane, which is placed in turn on the slope of a hillside. Diluted sulphuric acid is sprayed over ore heaps $100 \mathrm{~m}$ high with percolation enabled through the formed heap. This leads to the dissolution of copper and its penetration (Fig. 3).

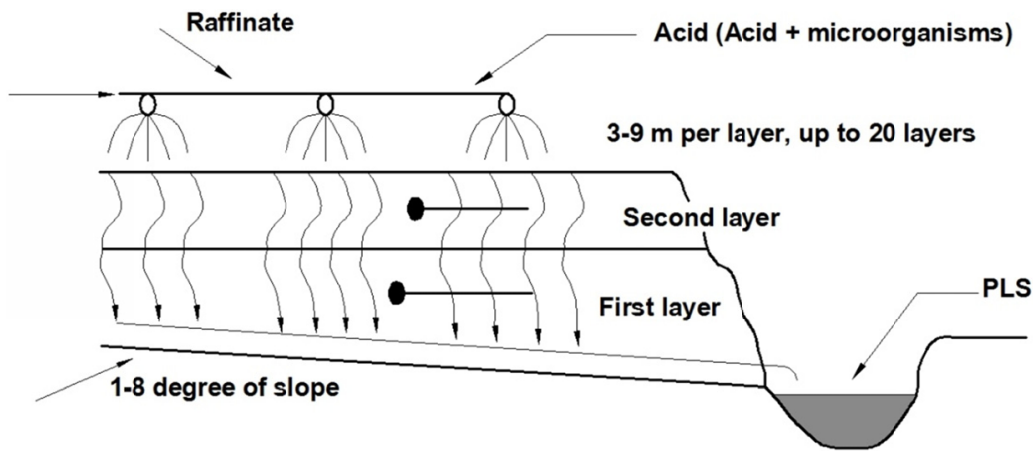

Fig. 3. Heap leaching

A membrane catches the solution during runoff and directs it into the open channel. In this way, leached ionic copper, known as pregnant leaching solution, or PLS, is then sent to a plant for solvent and electrolytic extraction (SX-EW) in order to obtain copper cathode of LME-A quality.

Fig. 4 presents a technological schema for the treatment of leaching liquor (PLS) using the method of SX (solvent extraction) and EW (electrolytic extraction).

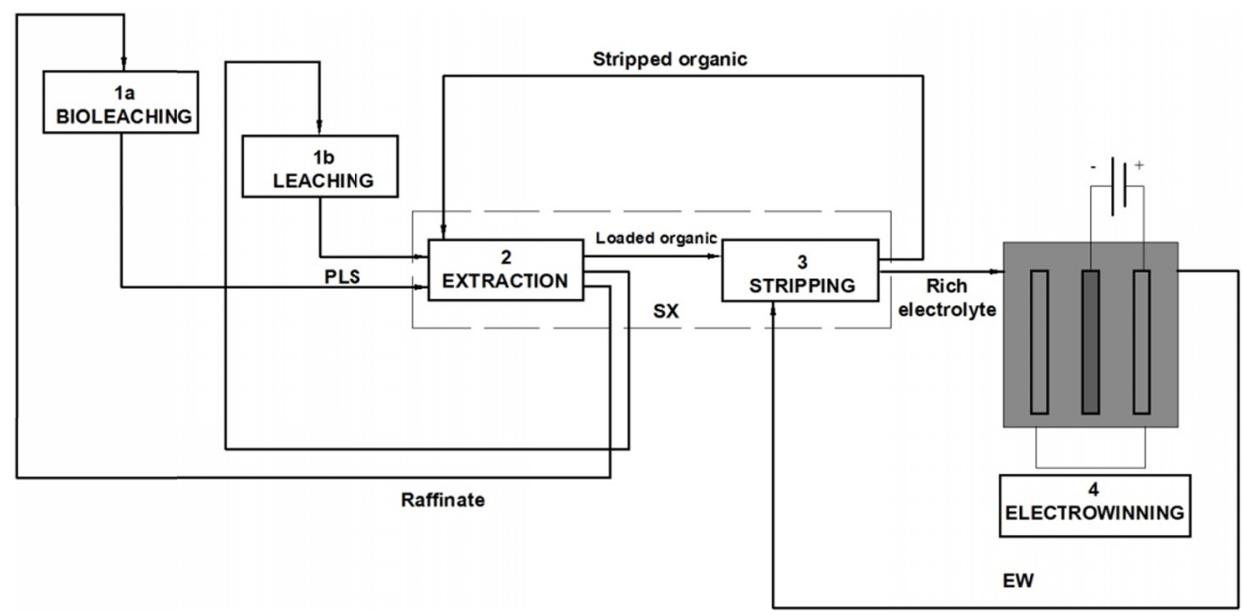

Fig. 4. Flow diagram of the L-SX-EW processes 
In the extraction process, the PLS comes into contact with an organic phase containing the organic extractant (Cvetkovski at al., 2009), which transfers the copper ions from the aqueous phase to the organic phase, leaving all other types of impurities present in the leaching solution in the aqueous phase. The organic phase, now enriched with copper, and the depleted aqueous phase (raffinate) are separated by gravity. The raffinate is returned to the circulating circle for leaching, where the acid produced in the extraction process can be used again as a raffinate (see Fig. 3). In the process of stripping, the enriched organic phase is brought into contact with a strongly acidic depleted electrolyte from the electrolytic extraction (EW), which strips the copper ions from the organic phase and transfers them to the electrolyte. The stripped organic phase and copper-enriched aqueous phase are separated by gravity. The former is fed back into the circuit for stripping in contact with a fresh leaching solution. The enriched electrolyte is returned to the electrolytic extraction, where the copper ions are reduced and electrochemically deposited on the cathode.

Over the course of the conducted research (Fouillac, 2006), during bench-scale tests, copper recovery of over $96 \%$ was achieved at $70^{\circ} \mathrm{C}$ on the fine-milled Veliki Krivelj copper concentrate to a particle of $\mathrm{d} 90=10-12 \mu \mathrm{m}$. Slightly lower levels of copper recovery of around $94 \%$ were obtained from the Majdanpek copper concentrate in eastern Serbia. The slag concentrate yielded copper extractions of above $95 \%$ at $70^{\circ} \mathrm{C}$, with no improvement over fine milling. A blend of concentrates (44\% V. Krivelj, 28\% Majdanpek, 28\% slag) was also tested, using fine-milled Veliki Krivelj and Majdanpek concentrates, and 'as-is' slag concentrate (d90=135 $\mu \mathrm{m})$. Copper recovery of $95 \%$ was obtained at $70^{\circ} \mathrm{C}, 10 \%$ feed solids concentration, $600 \mathrm{mV}$ vs $\mathrm{Ag} \mid \mathrm{AgCl}$ operating redox potential, and a total residence time of six days. Bioleaching has the advantage of incurring lower capital costs and the flexibility to treat concentrates with lower grades than can be treated using the smelter method (Robertson et al., 2008; Gericke et al., 2008).

Considering that the mineralogical composition of the ore is almost the same as that of the Kraku Bugaresku Cementacija ore, it can be assumed that the degree of leaching is about the same. For this reason, when calculating economic profitability, this method of ore treatment have been taken high efficiency.

Many metals can be leached out from the corresponding sulphides using the bacterial leaching method (Conić, 2015; Gericke et al., 2008). The sulphide minerals present in the Kraku Bugaresku Cementacija ore are pyrite, covellite, and chalcocite. The following reaction describes the direct mechanism of the oxidation of pyrite, $\mathrm{FeS}_{2}$ (Watling, 2006). In the direct mechanism, pyrite can be oxidised, using mesophilic microorganisms, into soluble sulphate according to reaction (3):

$$
\begin{gathered}
2 \mathrm{FeS}_{2}+15 \mathrm{O}_{2}+2 \mathrm{H}_{2} \mathrm{O} \rightarrow \mathrm{FeSO}_{4}+2 \mathrm{H}_{2} \mathrm{SO}_{4} \\
2 \mathrm{FeSO}_{4}+1 / 2 \mathrm{O}_{2}+\mathrm{H}_{2} \mathrm{SO}_{4}=\mathrm{Fe}_{2}\left(\mathrm{SO}_{4}\right)_{3}+\mathrm{H}_{2} \mathrm{O}
\end{gathered}
$$

An indirect mechanism for the oxidation of sulphide minerals of copper is represented by the oxidation of sulphides with ferric ions, according to reaction (5):

$$
\begin{gathered}
\mathrm{CuS}+\mathrm{Fe}_{2}\left(\mathrm{SO}_{4}\right)_{3} \rightarrow \mathrm{CuSO}_{4}+2 \mathrm{FeSO}_{4}+\mathrm{S}^{\mathrm{O}} \\
\mathrm{Cu}_{2} \mathrm{~S}+\mathrm{Fe}_{2}\left(\mathrm{SO}_{4}\right)_{3} \rightarrow \mathrm{CuSO}_{4}+2 \mathrm{FeSO}_{4}+\mathrm{CuS}^{\mathrm{o}}
\end{gathered}
$$


The cyclical process between reactions (3) and (4) is carried out by the mechanism of metal dissolution shown here. Through the formation of $\mathrm{H}^{+}$ions during the oxidation of sulphur, according to reaction (7), solubility and total recovery are increased.

$$
2 \mathrm{~S}^{\mathrm{o}}+3 \mathrm{O}_{2}+2 \mathrm{H}_{2} \mathrm{O} \rightarrow 4 \mathrm{H}_{2} \mathrm{SO}_{4}
$$

Sulphuric acid occurs by means of the direct or indirect action of bacteria on sulphide ore. Sulphuric acid improves the balance of acid and in this way creates a balance in the system. Moreover, the reaction is exothermic, and can be focused on raising the temperature, thereby improving the kinetics (Robertson, 2005).

Disruption of the crystal lattice of the sulphide mineral is due to the much larger ionic radii of sulphate ions. Thus, the microbes gain access to new unreacted areas (Vučetic, 1978).

The present oxide mineralisation in the Kraku Bugaresku Cementacija ore comprises cuprite, malachite, chrysocolla, and azurite (Watling, 2006). The action of weak sulphuric acid on these mineral grains results in easily soluble sulphates by means of reactions (8), (9), (10), and (11).

$$
\begin{gathered}
\mathrm{Cu}_{2} \mathrm{O}+2 \mathrm{H}^{+} \rightarrow \mathrm{Cu}^{2+}+\mathrm{Cu}^{0}+\mathrm{H}_{2} \mathrm{O} \\
\mathrm{CuCO}_{3} \times \mathrm{Cu}(\mathrm{OH})_{2}+2 \mathrm{H}_{2} \mathrm{SO}_{4}=2 \mathrm{CuSO}_{4}+\mathrm{CO}_{2}+3 \mathrm{H}_{2} \mathrm{O} \\
\mathrm{CuSiO}_{3} \times 2 \mathrm{H}_{2} \mathrm{O}+2 \mathrm{H}^{+}=\mathrm{Cu}^{2+}+\mathrm{SiO}_{2}+3 \mathrm{H}_{2} \mathrm{O} \\
2 \mathrm{CuCO}_{3} \times \mathrm{Cu}(\mathrm{OH})_{2}+3 \mathrm{H}_{2} \mathrm{SO}_{4}=3 \mathrm{CuSO}_{4}+2 \mathrm{CO}_{2}+4 \mathrm{H}_{2} \mathrm{O}
\end{gathered}
$$

Taking into account the information above, two variants can be defined for the analysis of long-term plan for ore mining and processing from the Kraku Bugaresku Cementacija deposit as follows:

- Variant 1: analysis of the technological process of mining and flotation processing ore with a copper oxide grade $\leq 10 \%$ (Ore 1), using a stockpile for ore with a copper oxide grade $>10 \%$ (Ore 2), the further treatment of which is not considered in this paper.

- Variant 2: analysis of the technological process of ore excavation and two types of processing: bioleaching of Ore 1 and acid leaching of Ore 2.

The aim of the analysis of these two variants is to optimise the economic results of mining the deposit throughout the life of the open pit.

Creating an optimum limit for the open pit and defining the optimum excavation dynamics, with the aim of maximising the NPV with real constraints in the production process, was done using the Whittle software program. Table 1 presents data representing the techno-economic parameters that were input for implementing the optimisation process in the software, which thus enables users to conduct extensive economic analyses and to compare the effects of different input parameters.

For each open pit the software calculates the amount of ore, the amount of overburden, the ore and overburden ratios, the average metal content in the ore, and profit and discounted profit by different periods and in total. The software also enables export of optimisation results within the output module.

The tables and graphs in the paper represent the unified output results from the software.

Fig. 5a and $\mathrm{b}$ presents schematic views of the mining process for Variants 1 and 2. 


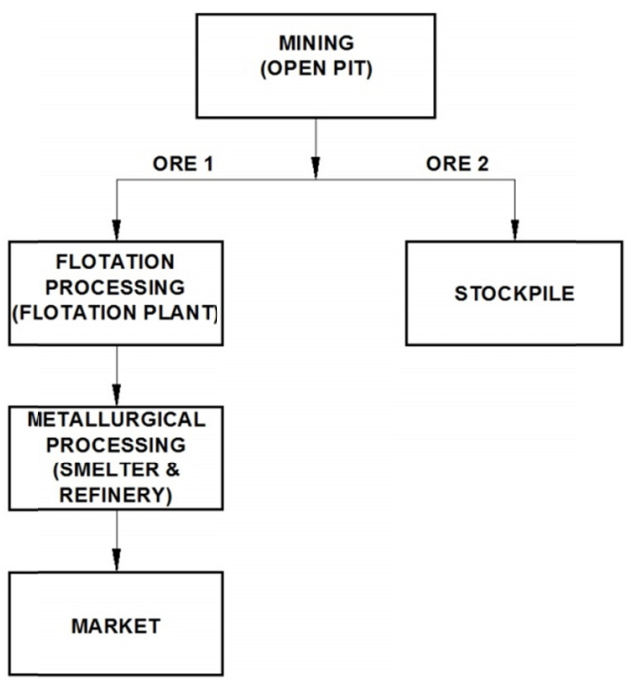

a) Variant 1

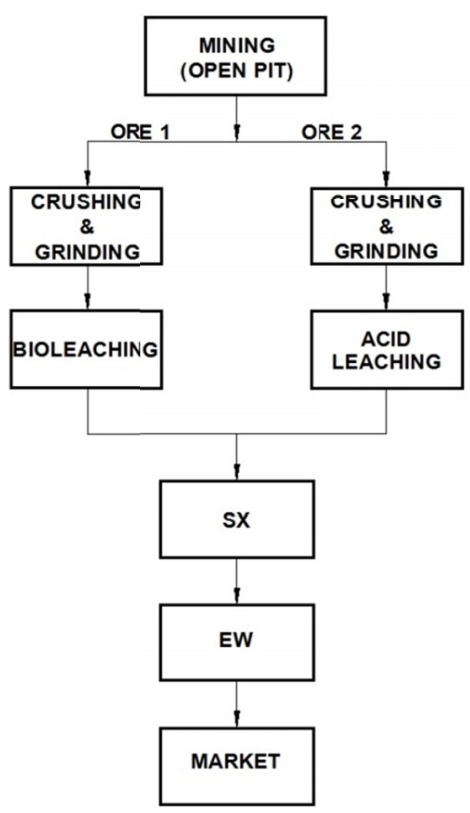

b) Variant 2

Fig. 5. Schematic view of the mining process

Capital costs of hydrometallurgical processing were estimated at around \$30 million.

Techno-economic parameters for optimisation of the open pit

\begin{tabular}{|l|c|c|c|}
\hline \multicolumn{1}{|c|}{ Parameter } & Unit & Variant 1 & Variant 2 \\
\hline \multicolumn{1}{|c|}{$\mathbf{1}$} & $\mathbf{2}$ & $\mathbf{3}$ & $\mathbf{4}$ \\
\hline Mining capacity & $\mathrm{t} / \mathrm{year}$ & $15,000,000$ & $15,000,000$ \\
\hline Processing capacity & $\mathrm{t} / \mathrm{year}$ & $5,500,000$ & $5,500,000$ \\
\hline Hydrometallurgical processing capacity - (Ore 1) & $\mathrm{t} / \mathrm{year}$ & - & $5,500,000$ \\
\hline Hydrometallurgical processing capacity - (Ore 2) & $\mathrm{t} / \mathrm{year}$ & - & 200,000 \\
\hline Copper selling price & $\$ / \mathrm{t}$ & 5,000 & 5,000 \\
\hline Gold selling price & $\$ / \mathrm{kg}$ & 35,000 & 35,000 \\
\hline Silver selling price & $\$ / \mathrm{kg}$ & 500 & 500 \\
\hline Mining cost & $\$ / \mathrm{t}$ & 1.5 & 1.5 \\
\hline Processing or milling cost & $\$ / \mathrm{t}$ & 6.0 & - \\
\hline Hydrometallurgical bioleaching processing cost (Ore 1) & $\$ / \mathrm{t}$ & - & 2.0 \\
\hline Hydrometallurgical leaching processing cost (Ore 2) & $\$ / \mathrm{t}$ & - & 1.0 \\
\hline Copper smelting refining cost & $\$ / \mathrm{t}$ & 450 & - \\
\hline Copper SX-EW cost & & - & 150 \\
\hline Gold refining cost & $\$ / \mathrm{kg}$ & 150 & 150 \\
\hline
\end{tabular}




\begin{tabular}{|l|c|c|c|}
\hline \multicolumn{1}{|c|}{$\mathbf{1}$} & $\mathbf{2}$ & $\mathbf{3}$ & $\mathbf{4}$ \\
\hline Silver refining cost & $\$ / \mathrm{kg}$ & 15 & 15 \\
\hline Copper recovery (processing and refining) & $\%$ & 0.784 & 0.902 \\
\hline Gold recovery (processing and refining) & $\%$ & 0.504 & 0.504 \\
\hline Silver recovery (processing and refining) & $\%$ & 0.396 & 0.396 \\
\hline Discount rate & $\%$ & 10 & 10 \\
\hline
\end{tabular}

\section{Results and discussion}

The following table and figure present a numerical and graphical representation of the results of the analysis conducted for Variants 1 and 2. Based on the analysis, it can be concluded that Variant 2 achieves better techno-economic results, as reflected in the following:

- a higher rate of recovery of mineral deposit is achieved;

- the life of the mine is longer by five years, which is important for the community. A longer life leads to a greater socio-economic impact, with a long-term increase in employment and increase in benefits to the employees and local community;

- an increase in NPV of $20.42 \%$ is achieved.

Table 2 and Fig. 6 show the results of schedule optimisation for Variant 1.

Table 3 and Fig. 7 show the results of schedule optimisation for Variant 2.

TABLE 2

Results of schedule optimisation for Variant 1

\begin{tabular}{|c|c|c|c|c|c|}
\hline \hline $\begin{array}{c}\text { Period } \\
\text { (Year) }\end{array}$ & $\begin{array}{c}\text { Ore 1 } \\
\mathbf{( t )}\end{array}$ & $\begin{array}{c}\text { Waste } \\
\mathbf{( t )}\end{array}$ & $\begin{array}{c}\text { Average grade Cu } \\
\mathbf{( \% )}\end{array}$ & $\begin{array}{c}\text { Cash flow } \\
\text { (\$ undiscounted) }\end{array}$ & $\begin{array}{c}\text { Cash flow } \\
\text { (\$ discounted) }\end{array}$ \\
\hline $\mathbf{1}$ & $\mathbf{2}$ & $\mathbf{3}$ & $\mathbf{4}$ & $\mathbf{5}$ & $\mathbf{6}$ \\
\hline 1 & $2,593,685$ & $12,406,315$ & 0.243 & $-14,632,876$ & $-13,302,615$ \\
\hline 2 & $5,500,000$ & $8,537,981$ & 0.321 & $21,591,812$ & $17,844,472$ \\
\hline 3 & $5,500,000$ & $5,475,439$ & 0.332 & $30,428,384$ & $22,861,295$ \\
\hline 4 & $5,500,000$ & $4,380,306$ & 0.274 & $21,113,804$ & $14,421,012$ \\
\hline 5 & $5,500,000$ & $4,355,523$ & 0.265 & $18,520,146$ & $11,499,553$ \\
\hline 6 & $5,500,000$ & $3,201,729$ & 0.286 & $25,486,309$ & $14,386,357$ \\
\hline 7 & $5,500,000$ & $2,417,977$ & 0.303 & $32,645,052$ & $15,752,074$ \\
\hline 8 & $5,500,000$ & $2,639,873$ & 0.273 & $25,139,900$ & $9,727,949$ \\
\hline 9 & $5,500,000$ & $2,723,351$ & 0.245 & $18,535,091$ & $6,860,688$ \\
\hline 10 & $5,500,000$ & $3,198,482$ & 0.225 & $12,650,494$ & $4,877,313$ \\
\hline 11 & $5,500,000$ & $1,630,253$ & 0.219 & $13,883,930$ & $4,866,233$ \\
\hline 12 & $5,500,000$ & $1,661,772$ & 0.234 & $15,814,474$ & $5,038,979$ \\
\hline 13 & $5,500,000$ & $1,092,503$ & 0.248 & $21,846,109$ & $6,328,040$ \\
\hline 14 & $5,500,000$ & 576,390 & 0.231 & $20,262,135$ & $5,335,653$ \\
\hline 15 & 926,874 & 0 & 0.274 & $6,358,282$ & $1,647,656$ \\
\hline Total & $\mathbf{7 5 , 0 2 0 , 5 5 9}$ & $\mathbf{5 4 , 2 9 7 , 8 9 4}$ & $\mathbf{0 . 2 6 5}$ & $\mathbf{2 6 9 , 6 4 3 , 0 4 6}$ & $\mathbf{1 2 8 , 1 4 4 , 6 5 9}$ \\
\hline
\end{tabular}




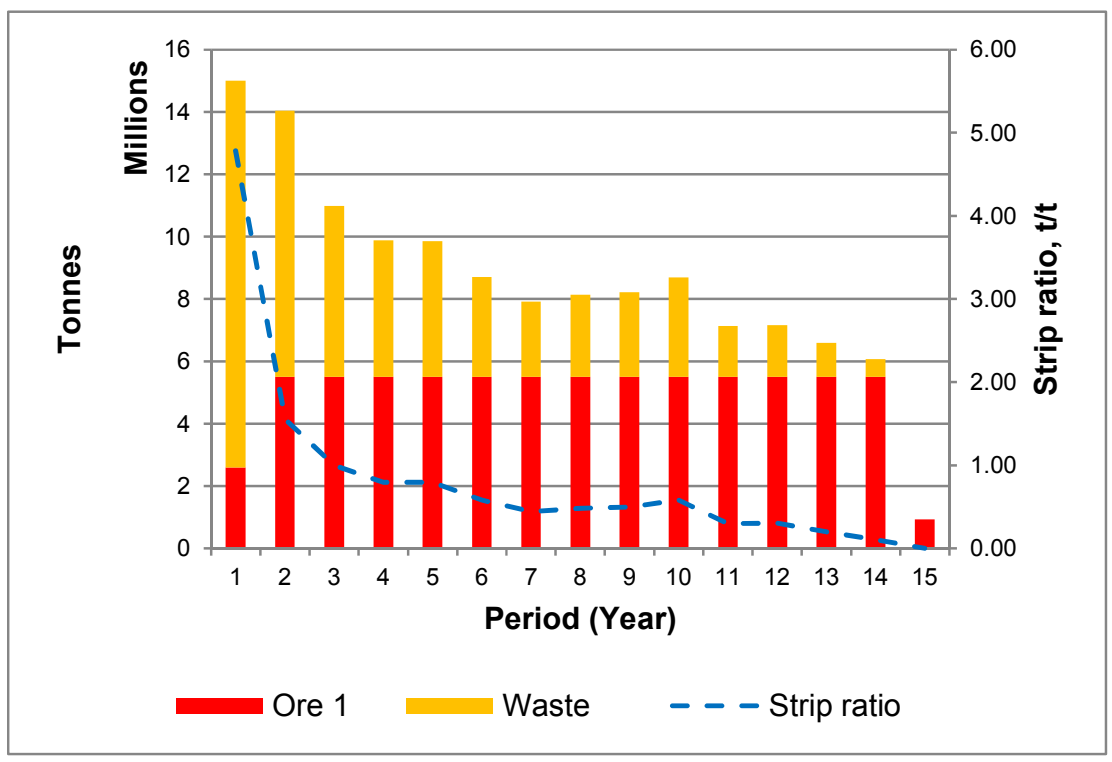

Fig. 6. Graphic view of the optimum schedule, Variant 1

Results of schedule optimisation for Variant 2

\begin{tabular}{|c|c|c|c|c|c|c|c|}
\hline \hline $\begin{array}{c}\text { Period } \\
\text { (Year) }\end{array}$ & $\begin{array}{c}\text { Ore 1 } \\
\mathbf{( t )}\end{array}$ & $\begin{array}{c}\text { Ore 2 } \\
\mathbf{( t )}\end{array}$ & $\begin{array}{c}\text { Waste } \\
\mathbf{( t )}\end{array}$ & $\begin{array}{c}\text { Average } \\
\text { grade Cu } \\
\text { Ore 1 } \\
\mathbf{( \% )}\end{array}$ & $\begin{array}{c}\text { Average } \\
\text { grade Cu } \\
\text { Ore 2 } \\
\mathbf{( \% )}\end{array}$ & $\begin{array}{c}\text { Cash } \\
\text { flow } \\
\text { (\$ undisco- } \\
\text { unted) }\end{array}$ & $\begin{array}{c}\text { Cash flow } \\
\text { (\$ disc) }\end{array}$ \\
\hline $\mathbf{1}$ & $\mathbf{2}$ & $\mathbf{3}$ & $\mathbf{4}$ & $\mathbf{5}$ & $\mathbf{6}$ & $\mathbf{7}$ & $\mathbf{8}$ \\
\hline 1 & $2,425,883$ & 21,762 & $12,552,355$ & 0.227 & 0.412 & $-7,166,671$ & $-6,515,155$ \\
\hline 2 & $2,445,359$ & 59,076 & $12,495,564$ & 0.191 & 0.465 & $-11,424,307$ & $-9,441,576$ \\
\hline 3 & $2,408,038$ & 110,955 & $12,481,008$ & 0.212 & 0.459 & $-9,411,869$ & $-7,071,277$ \\
\hline 4 & $3,267,708$ & 103,569 & $11,628,723$ & 0.225 & 0.357 & 57,595 & 39,338 \\
\hline 5 & $5,279,875$ & 120,025 & $9,600,100$ & 0.187 & 0.356 & $9,133,660$ & $5,671,284$ \\
\hline 6 & $5,476,741$ & 111,186 & $4,261,894$ & 0.218 & 0.368 & $29,455,336$ & $16,626,769$ \\
\hline 7 & $5,401,341$ & 160,409 & $3,470,079$ & 0.236 & 0.317 & $35,414,938$ & $18,173,463$ \\
\hline 8 & $5,357,861$ & 199,223 & $4,036,142$ & 0.252 & 0.258 & $37,432,976$ & $17,462,759$ \\
\hline 9 & $5,316,306$ & 234,618 & $4,783,187$ & 0.272 & 0.223 & $40,096,228$ & $17,004,715$ \\
\hline 10 & $5,298,151$ & 246,927 & $3,254,849$ & 0.255 & 0.213 & $39,618,824$ & $15,274,772$ \\
\hline 11 & $5,389,578$ & 153,793 & $2,808,958$ & 0.246 & 0.221 & $39,479,543$ & $13,837,339$ \\
\hline 12 & $5,475,939$ & 39,185 & $2,992,394$ & 0.226 & 0.208 & $35,092,237$ & $11,181,468$ \\
\hline 13 & $5,509,040$ & & $2,850,264$ & 0.223 & & $34,823,422$ & $10,087,105$ \\
\hline 14 & $5,503,196$ & & $2,516,862$ & 0.224 & & $35,299,157$ & $9,295,371$ \\
\hline 15 & $5,506,422$ & & $1,866,204$ & 0.227 & & $38,168,910$ & $9,137,334$ \\
\hline 16 & $5,502,302$ & & $1,476,876$ & 0.239 & & $42,515,916$ & $9,252,702$ \\
\hline 17 & $5,499,997$ & & $1,129,955$ & 0.237 & & $41,856,862$ & $8,281,157$ \\
\hline
\end{tabular}




\begin{tabular}{|c|c|c|c|c|c|c|c|}
\hline $\mathbf{1}$ & $\mathbf{2}$ & $\mathbf{3}$ & $\mathbf{4}$ & $\mathbf{5}$ & $\mathbf{6}$ & $\mathbf{7}$ & $\mathbf{8}$ \\
\hline 18 & $5,499,999$ & & $1,052,832$ & 0.233 & & $39,501,632$ & $7,104,716$ \\
\hline 19 & $5,500,000$ & & 710,248 & 0.246 & & $47,721,448$ & $7,802,838$ \\
\hline 20 & 840,601 & & 7,861 & 0.232 & & $6,896,436$ & $1,111,316$ \\
\hline Total & $\mathbf{9 2 , 9 0 4 , 3 3 6}$ & $\mathbf{1 , 5 6 0 , 7 2 9}$ & $\mathbf{9 5 , 9 7 6 , 3 5 5}$ & $\mathbf{0 . 2 2 7}$ & $\mathbf{0 . 2 9 3}$ & $\mathbf{5 2 4 , 5 6 2 , 2 7 3}$ & $\mathbf{1 5 4 , 3 1 6 , 4 3 8}$ \\
\hline
\end{tabular}

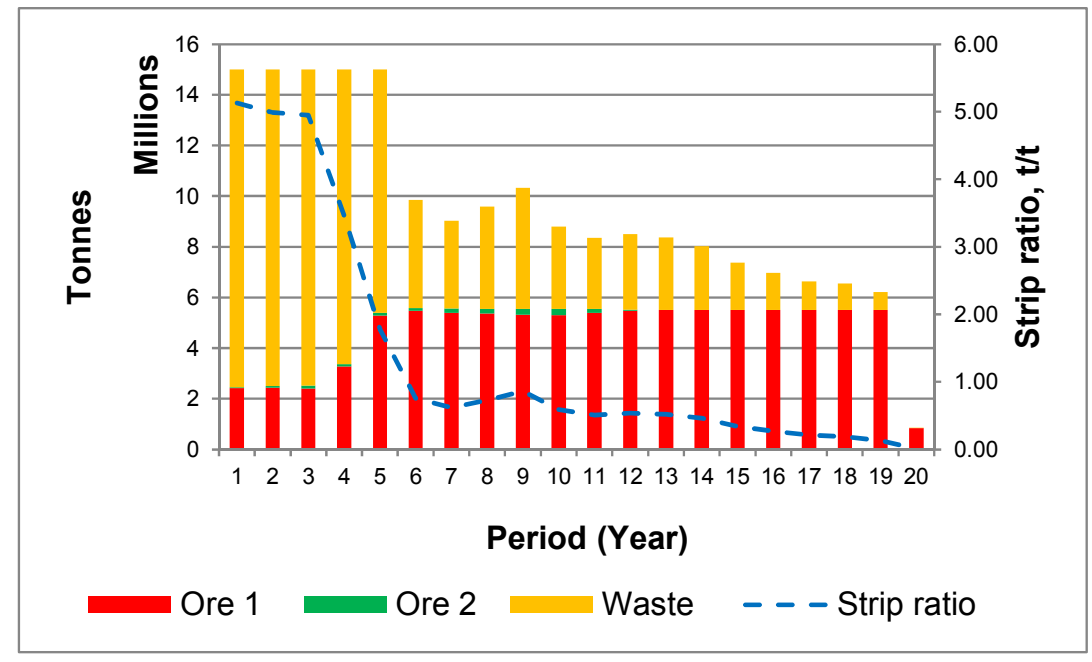

Fig. 7. Graphic view the optimum schedule, Variant 2

Fig. 8 shows flows for the average $\mathrm{Cu}$ grade; Fig. 9 shows discounted and undiscounted cash flows by periods of exploitation for Variants 1 and 2.

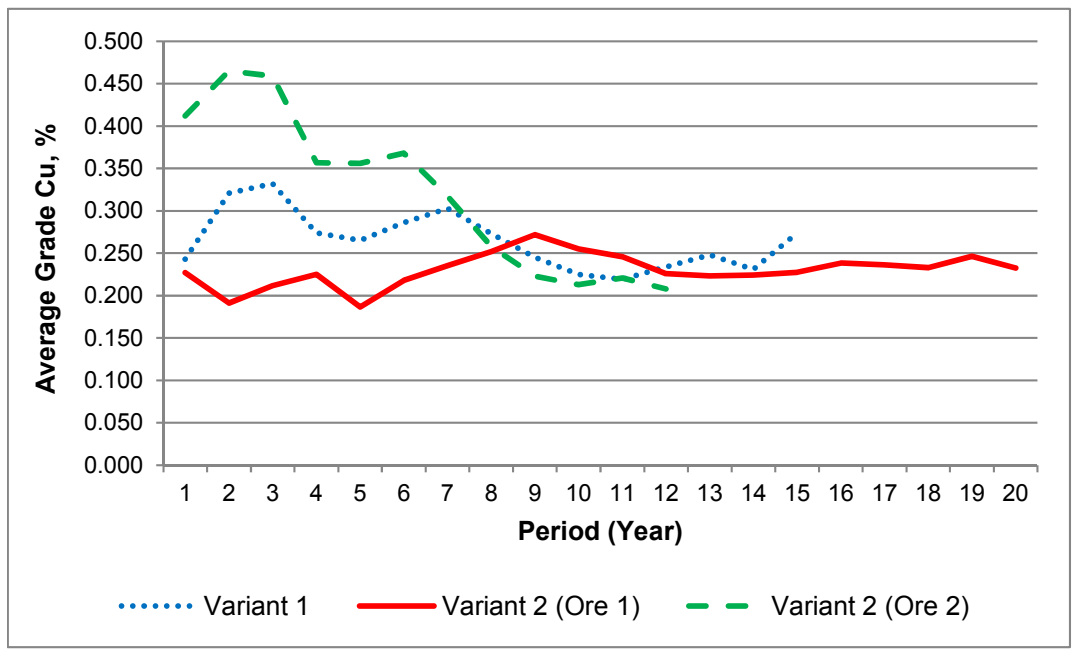

Fig. 8. Flows for the average grade of copper for the life of the mine 


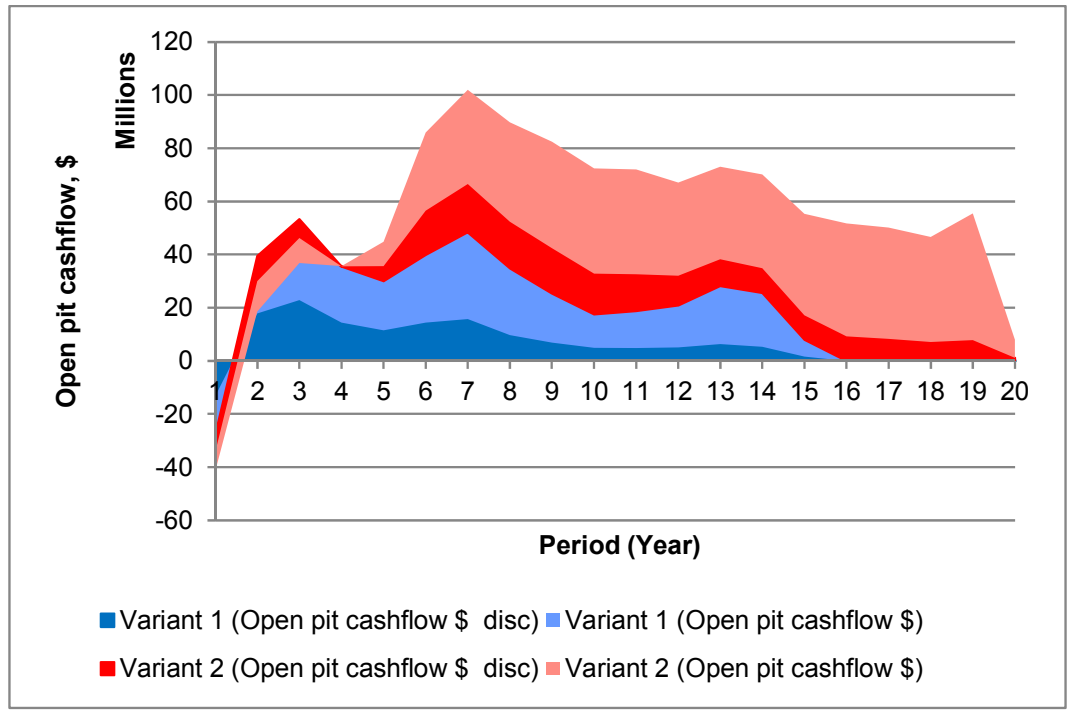

Fig. 9. Discounted and undiscounted cash flows for the life of the mine

The graphs in Figs. 8 and 9 indicate the following:

- In Variant 2, the cash flows are negative in the first three years of exploitation, as opposed to Variant 1, where a negative value of cash flow occurs only in the first year.

- Although the average cut-off grade of $\mathrm{Cu}$ in Variant 2 is lower in the first nine years, higher cash flows are realised due to lower unit operating costs of processing. It should be noted here that the average $\mathrm{Cu}$ grade in the ore with the copper oxide grade over $10 \%$ (Ore 2) is significantly higher than the average $\mathrm{Cu}$ grade in Ore 1, but these grades also affect the likely increase in cash flows, since small quantities of ore are involved.

- An overall NPV higher than that of Variant 1 by $\$ 26,171,779$ is achieved in Variant 2.

\section{Conclusion}

Long-term planning for open pits involves a comprehensive multidisciplinary process that depends both on natural conditions prevailing in the deposit and technical and economical parameters of ore mining and processing. The geometry of the deposit, distribution of useful components within the deposit, costs, market prices for metal, and the technology and capacity for mining and processing are crucial for evaluation of a given mining project.

In this sense, the use of methods of geostatistical modelling and methods of long-term planning and optimisation of open pits should ensure identification of the optimum solution even in the planning stage. Implementation of this solution will achieve maximisation of NPV value in actual conditions of ore mining in open pits.

This case study presents a procedure for long-term planning for open pits of copper sulphideoxide ore. The analysis was carried out for the mining and flotation processing of Ore 1 with the use of a stockpile for Ore 2 (Variant 1), as well as for the mining and hydrometallurgical processing of ore involving the bioleaching of Ore 1 and acid leaching of Ore 2 (Variant 2). 
The use of hydrometallurgical processing of copper ore is characterised by the following:

- enhanced recovery of deposit reserves, since it is possible to process the oxide ore without any additional capital costs, which is not possible in the process of flotation processing. In this way, an additional 1,560,729 tons of ore were processed, whereby 4,127 tons of copper cathode were produced.

- realisation of lower unit operating costs and greater technological efficiencies in the ore processing.

Finally, the analysis shows that the use of hydrometallurgical ore processing (Variant 2) results in an increase of NPV of $20.42 \%$, or $\$ 26,171,779$.

\section{References}

Angelov T., Savov G., Tsekov A., Nishkov I., 2015. The successful commercial implementation of the combined leach-ion exchange-solvent extraction-electrowinning process at the Bucim copper project, Proceedings of Alta, Nickel-Cobalt-Copper session, 25-27 May, Perth, Australia, pp. 1-8.

Armstrong D., 1990. Planning and design of surface mines. B. A. Kennedy (Ed.), Surface Mining (second ed.). Littleton, Colorado, USA: Society for Mining, Metallurgy and Exploration Inc., pp. 459-475.

Caccetta L., 2007. Application of optimisation techniques in open pit mining, Handbook of Operations Research in Natural Resources, Volume 99 of the series International Series in Operations Research amp; Mana pp. 547-559.

Caccetta L., Hill S.P., 2003. An Application of Branch and Cut to Open Pit Mine Scheduling. Journal of Global Optimization, vol. 27, pp. 349-365.

Conić V., 2015. Biotechnology for treatment of complex sulphide concentrate. Doctoral dissertation, (in Serbian), University of Belgrade - Technical Faculty in Bor.

Cvetkovski V., Conić V., Vuković M., Stojanovski G., Cvetkovska M., 2009. Construction of Isotherms in the Solvent Copper Extraction. Hemijska industrija 63 (4), pp. 309-312 [in Serbian].

David M., 1973. Tools for planning: Variances and conditional simulation. J.R. Sturgul (Ed.) 11th APCOM University of Arizona, pp. D10-D23.

David M., Dowd P.A., Korobov S., 1974. Forecasting departure from planning in open pit design and grade control. 12th APCOM Symposium Colorado School of Mines, pp. F131-F153.

Davis G., Newman A., 2008. Modern Strategic Mine Planning. http://inside.mines.edu/ gdavis/Papers/CRC_Mining_Conference_Paper.pdf

Dimitrakopoulos R., 2006. Conditional simulation algorithms for modelling orebody uncertainty in open pit optimization. Int. J. Min. Reclamation Environ., vol. 12, pp. 173-179.

Fan Z.C., Wang J.M., Hao Q.M., 2003. Optimising Open Pit Mine Production Scheduling by Graph Theory, Mine Planning and Equipment Selection. Kalgoorlie, WA, 23-25 April, pp. 447-454, http://www.ausimm.com.au/publications/ epublicati on.aspx?ID=795.

Fouillac C., 2006. BioMinE project, Contract No. 500329, BRGM.

Gericke M., Conić V., Cvetkovski V., Milanović D., Vuković M., Milanović S., 2008. Bioleaching of the Majdanpek and $V$. Krivelj concentrates. IOC on Mining and Metallurgy, Sokobanja, pp. 256-262.

Gericke M., Muller H.H., Staden P.J., Pinches A., 2008. Development of a tank bioleaching process for the treatment of complex Cu-polymetallic concentrates. Hydrometallurgy, 94, pp. 23-28.

Davis G.A., Newman A.M., 2008. Modern Strategic Mine Planning, Colorado School of Mines, http://inside.mines. edu/ gdavis/Papers/CRC_Mining_Conference_Paper.pdf.

Johnson T.B., 1969. Optimum production scheduling. Proceedings of 8th APCOM symp., Salt Lake City, Utah, pp. 539-562. Journel A., Kyriakidis P.C., 2004. Evaluation of mineral reserves: A simulation approach. Oxford University Press, p. 215. 
Kržanović D., Kolonja B., Stevanović D., 2015. Maximizing the net present value by applying an optimal cut-off grade for long-term planning of the copper open pits. Acta Montanistica Slovaca, The Union of Metallurgy, Mining Industry and Geology of Slovak Republic, the Slovak Mining Society, the Faculty of Mining, Ecology, Process Control and Geotechnologies (FBERG) of the Technical University of Kosice (Slovakia), and the Faculty of Mining and Geology (HGF) of the VSB Technical University of Ostrava (Czech Republic), Vol. 20 (2015), nu. 1, pp. 49-61, http://actamont.tuke.sk/ams2015.html.

Kržanović D., Rajković R., Mikić M., Ljubojev M., 2014. Effect of stage development of mining operations on maximization of the net present value in long-term planning of open pits. Mining and Metallurgy Engineering Bor, 4/2014, Mining and Metallurgy Institute Bor, DOI:10.5937/MMEB1404033K, pp. 33-40.

Lerchs H., Grossmann I.F., 1965. Optimum Design of Open Pit Mines. Transactions, Canadian Institute of Mining and Metallurgy, Vol. LXVIII, pp. 17-24.

Nelson S., Rolf F., Pierre P., Alejandro V., Los B., 2008. Development Project. The Southern African Institute of Mining and Metallurgy Surface Mining, pp. 79-92.

Ramazan S., Dimitrakopoulos R., 2004a. Recent application of operation research and efficient MIP formulation in open-pit mining. Society for Mining Metallurgy and Exploration. Transactions, 316, pp. 73-78.

Ramazan S., Dimitrakopoulos R., 2004b. Traditional and New MIP Models for Production Scheduling with In-Situ Grade Variability. International Journal of Surface Mining, Vol. 18, pp. 85-98.

Robertson S., Neale J., Muller H., Gericke M., 2008. Deliverable: DIV8A BioMinE - FP6 Project IP NMP2-CT-2005-500329, report entitled $\mathrm{Cu} \&$ Cu polymetallics: report on piloting operation and pre-feasibility study for RTB Bor copper concentrates, pp. 1-55.

Robertson S.W., Vercuil A., Van Staden P.J, Craven P., 2005. A bacterial heap leaching approach for the treatment of low grade primary copper sulphide ore. The Third Southern African Conference on Base Metals, South Africa, pp. 471-484.

Source: Mining and Smelting Complex Bor - Group, 2015.

Sturgul J.R., Li Z., 1997. New developments in simulation technology and applications in the minerals industry. Int. J. Mining Reclamation Environ, vol. 11, pp. 159-162.

Swart R., Cramer K., Castro O., Tasker P., Forgan R., 2007. Evolution of copper solvent extraction reagents. Hydrocopper, IV International Cooper Hydrometallurgy Workshop, Viña del Mar, Chile, pp. 41-47.

Tinkler O., Shiels D., Soderstrom M., 2009. The ACORGA ${ }^{\circledR} O P T$ series: comparative studies against aldoxime: ketoxime reagents. Hydrometallurgy Conference, The Southern African Institute of Mining and Metallurgy, pp. 272-282.

Tolwinsky, B., Underwood R., 1996. A scheduling algorithm for open pit mines. IMA J. Manage. Math., vol. 7, pp. $247-270$.

Vučetic J., Vrvić M., Vujović B., 1978. The Use of Tiobacteria Isolated from Tailing Dump and Waste Water in Bor for Leaching the Bor Tailings. Faculty of Mining and Metallurgy and Copper Institute Bor, Proceedings, p. 157 (in Serbian).

Watling H.R., 2006. The bioleaching of sulphide minerals with emphasis on copper sulphides - A review. Hydrometallurgy, 84, pp. 81-108.

Whittle J., 1999. A decade of open pit mine planning and optimization - The craft of turning algorithms into packages. Proceedings of the 28th APCOM symposium, Golden, Colorado School of Mines, pp. 15-24.

Whittle User's Guide, 2014. Geovia, Dassault Systèmes. 